\title{
Effects of Thermo-Hydro-Mechanical Treatments on Various Physical and Mechanical Properties of Poplar (Populus) Wood
}

\begin{abstract}
Yali Shao, ${ }^{\mathrm{a}, \mathrm{b}}$ Lili Li, ${ }^{\mathrm{a}}$ Zhangjing Chen, ${ }^{\mathrm{c}}$ Sunguo Wang, ${ }^{\mathrm{d}}$ and Ximing Wang ${ }^{\mathrm{a}, *}$
Poplar (Populus) wood was subjected in this work to thermo-hydromechanical treatment. The influence of the treatment parameters on the physical and mechanical properties were investigated. The wood samples were densified under three compression ratios $(0 \%, 30 \%$, and $50 \%)$, and thermally treated at three temperatures $\left(180^{\circ} \mathrm{C}, 200^{\circ} \mathrm{C}\right.$, and $\left.220^{\circ} \mathrm{C}\right)$, at three thermal treatment durations ( $3 \mathrm{~h}, 4 \mathrm{~h}$, and $5 \mathrm{~h}$ ). The density, modulus of elasticity, modulus of rupture, radial hardness, and thickness swelling were measured. The results showed that the densities of the samples increased by $36.6 \%$ to $49.7 \%$. As the compression rate increased, the temperature, duration, modulus of elasticity, modulus of rupture, and hardness increased. However, the dimensions of the densified samples were less stable. Compared to the densified samples, the maximum thickness swelling could be reduced by $74 \%$ (from $29.7 \%$ to $7.8 \%$ ) when subjected to a thermal treatment at $220^{\circ} \mathrm{C}$ for $3 \mathrm{~h}$.
\end{abstract}

Keywords: Densification; Heat treatment; Physical properties; Mechanical properties

Contact information: a: College of Material Science and Art Design, Inner Mongolia Agricultural University, Hohhot 010018 China; b: College of Art Design, Inner Mongolia Technical College of Construction, Hohhot 010070 China; c: Department of Sustainable Biomaterials, Virginia Polytechnic Institute and State University, Blacksburg, Virginia 24060 USA; d: Sungro Bioresource and Bioenergy Technologies Corp. 2334 Taylor Close NW, Edmonton, Alberta T6R 3J6 Canada;

*Corresponding authors: wangximing@imau.edu.cn; w_ximing@263.net

\section{INTRODUCTION}

Wood has been used as a structural material for building and furniture construction for thousands of years, primarily due to its low cost, abundance, and renewability (Boonstra and Tjeerdsma 2006). However, some qualities of wood are unsatisfactory for many applications, i.e., low density, poor mechanical properties, poor dimensional stability, and poor durability (Drafz et al. 2005; Kutnar and Kamke 2012). The physical and mechanical properties of wood are closely related to its density (Tu et al. 2014). Thus, considerable wood modification technologies have been proposed to increase the density of wood-based materials. Generally, the densification of wood materials can be accomplished via three different methods: mechanical compression, resin impregnation, or a combination of mechanical compression and impregnation method (Kollmann et al. 1975; Navi and Heger 2004; Kutnar et al. 2008). Among those densification methods, mechanical compression is the simplest and probably the most cost-efficient method (Dwianto et al. 2000).

During mechanical compression, the wood is compressed to the desired thickness between heated plates and the deformation is finalized in the compressed state. The void volumes in wood may be reduced by compressing the wood structure (usually in the radial direction), under the suitable moisture and temperature conditions, without the addition of 
any chemicals. After mechanical densification, the physical and mechanical properties of the wood is improved, e.g., the hardness, abrasion resistance, modulus of elasticity (MOE) and modulus of rupture (MOR), primarily due to the density of the wood increasing (Sandberg et al. 2013). Generally, most of the physical and mechanical properties of wood largely depend on the compression ratio (Belt et al. 2013). A study by Pelit et al. (2015) densified Scots pine and Eastern beech samples using a specially designed hydraulic press, with target compression ratios of $20 \%$ and $40 \%$. Pelit et al. (2015) found that the density was increased by $42 \%$ for the Scots pine samples in proportion to the compression ratios, and 35\% for the Eastern beech samples. In another study, Laine et al. (2016) studied the influence of the compression ratio $(\mathrm{CR}=40 \%, 50 \%$, and $60 \%)$ on the hardness and setrecovery of densified wood. Based on the findings of Laine et al. (2016), they concluded that the hardness drastically increased (in some circumstances doubled) relative to nondensified samples with a CR of 50\%. Song et al. (2018) processed wood to have a higher specific strength than most structural metals and alloys. Song et al. (2018) reported a twostep process involving the partial removal of lignins and hemicelluloses from the natural wood, following by hot-pressing, which led to the total collapse of the cell walls and the complete densification of the natural wood with highly aligned cellulose nanofibres.

Although mechanical densification has been developed, the set recovery of wood densification remains in question. Although the plasticized deformation of compressed wood does not change under dry conditions, wood completely recovers when the compressed wood is re-wet or boiled in water (Welzbacher et al. 2008). The structure of wood cells and the properties of cell wall polymers are responsible for the compressionrecovery behavior of wood (Kutnar and Šrnek 2007). Post-high-temperature heattreatment also could assist in solving set recovery problem through the modification of chemical components in compression wood (Gong et al. 2010). Many researchers have attempted to fix the shape recovery of densified wood, through thermo-hydro-mechanical (THM) compression and thermo-mechanical (TH) compression, which promotes crosslinking of chemical components, or releases inner chemical stresses to fix the deformation of the compressed wood (Navi and Heger 2004; Kutnar and Kamke 2012; Gao et al. 2016).

Thermo-hydro-mechanical (THM) processes as a physical modification were developed in late $20^{\text {th }}$ century, which includes mechanical and hydrostatic compression via the addition of steam and/or heat $\left(160^{\circ} \mathrm{C}\right.$ to $250{ }^{\circ} \mathrm{C}$ ) (Inoue et al. 1993; Kutnar et al. 2009; Kutnar et al. 2015). The THM processes, at thermal treatment temperatures ranging from $160{ }^{\circ} \mathrm{C}$ to $250{ }^{\circ} \mathrm{C}$, were found to improve the decay resistance, lower hygroscopicity, and enhance dimensional stability. Popescu et al. (2014) studied the influence of thermal treatments on wood samples. The set recovery tests showed that a higher temperature and longer duration improved the dimensional stability of the wood sample. Yin et al. (2016) used Raman microscopy (CRM) and X-ray diffraction to investigate the changes in the chemical composition and cellulose crystalline structure of spruce wood cell walls via THM treatment. The CRM results revealed that the crystallinity index and crystallite thickness of the samples increased due to the crystallization of the semicrystalline region and $\beta$-aryl-ether links. The crystallization process was associated with the guaiacyl units of the lignins, which were depolymerized after the re-condensation reactions. The crystallization of cellulose and lignin $\beta$-aryl-ether links are considered to be the reasons causing an increase in dimensional stability. However, the thermal treatment caused a loss of mass and consequently, a decrease in the density of the wood. Tomislav et al. (2019) studied changes in the Brinell hardness rating of beech wood and hornbeam wood, and found that thermal modification reduced the Brinell hardness rating of beech wood and 
hornbeam wood by $3 \%$ and $6 \%$ for the cross sections, by $15 \%$ and $18 \%$ for radial sections, and by $25 \%$ and $13 \%$ for tangential sections, respectively. This result indicated that the thermal treatment negatively influenced the Brinell hardness value of wood.

Thermo-hydro-mechanical treated wood has all the advantages of compressed wood and thermal treatment wood, with higher density and mechanical properties, as well as better dimensional stability. Therefore, the aim in this study was to examine the influence of the compression ratio, thermal treatment temperature, and duration on the density profile, MOE, MOR, hardness, and set recovery of THM treatment wood. In addition, this study examined how density influences the hardness and mechanical properties of THM treated wood.

\section{EXPERIMENTAL}

\section{Materials}

Preparation of the specimens

Beijing Poplar (Populus x beijingensis W. Y. Hsu) specimens without any defects were obtained from Inner Mongolia as logs with diameters between 28 and $38 \mathrm{~cm}$. Sample dimensions were as follows: $400 \mathrm{~mm}$ (longitudinal) x $150 \mathrm{~mm}$ (tangential) x $30 \mathrm{~mm}$ (radial). Because the growth cycle is short, Beijing poplar wood with low density, low strength, poor material, and no decay or other defects was obtained. The oven-dried density of the wood was $395 \mathrm{~kg} / \mathrm{m}^{3}$. The initial moisture content of all the samples was $25 \%$ to $30 \%$, and the initial moisture content of the samples was measured with a hygrometer (KT50B, Klonteser Co., Rome, Italy).

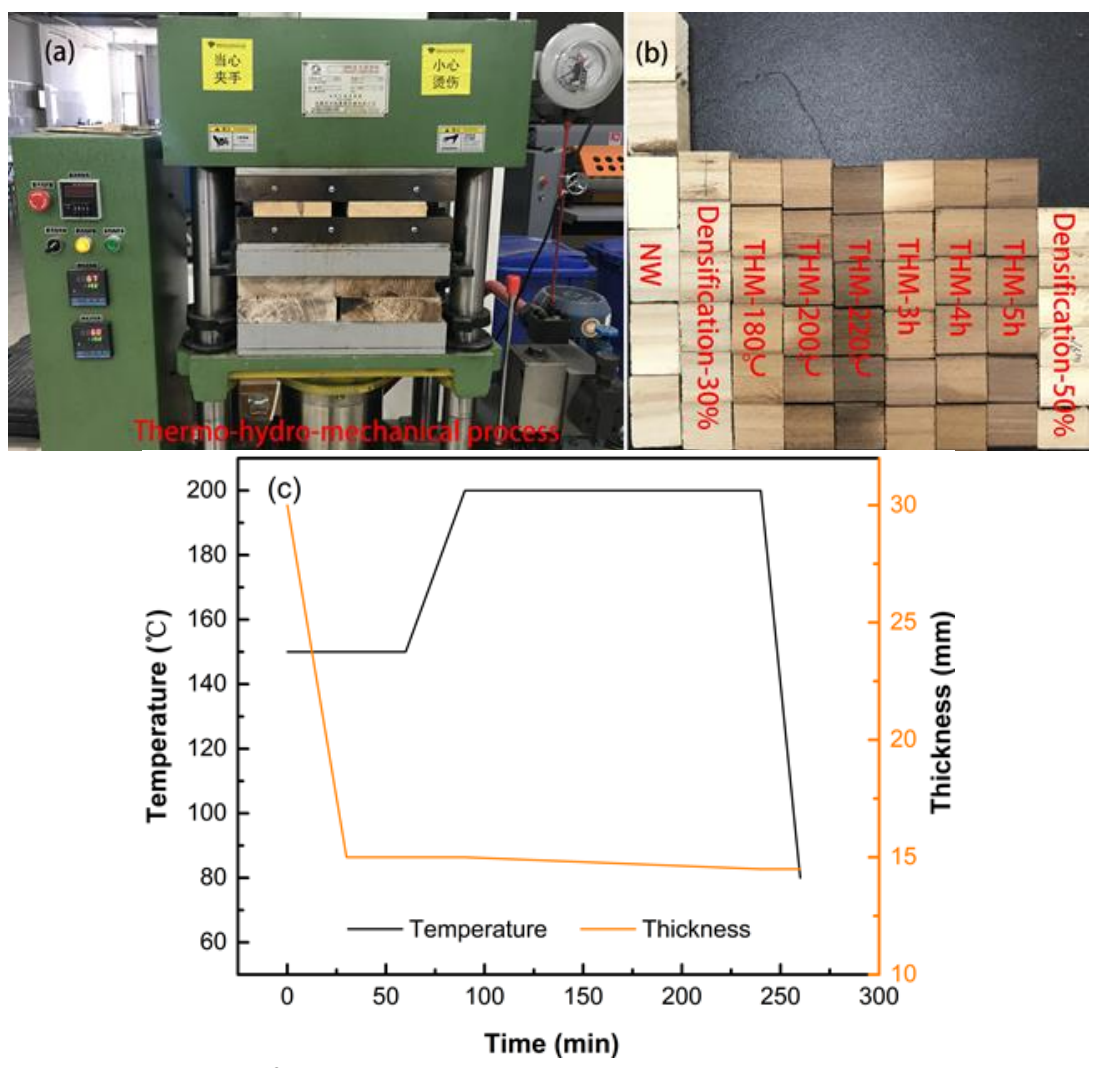

Fig. 1. The processing steps of the thermo-hydro-mechanical process 


\section{Thermo-hydro-mechanical process}

The thermo-hydro-mechanical process was composed of three processing steps (Fig. 1). First, the specimens were pressed in the radial direction at $150{ }^{\circ} \mathrm{C}$ under a pressure of approximately $4 \mathrm{MPa}$ for approximately $30 \mathrm{~min}$ to obtain the compressed wood. The thickness of the specimens was controlled with metal stops at three different target compression ratios: $0 \%, 30 \%$, and $50 \%$. Then, the samples were dried under a constant temperature $\left(150{ }^{\circ} \mathrm{C}\right)$ and pressure $(4 \mathrm{MPa})$ for approximately $30 \mathrm{~min}$. Heat treatment can reduce the set-recovery of compressed wood. Therefore, after drying, the samples were directly heat-treated with a hot press at the designated temperatures and durations (Table 1). The three important processes of THM processing are all completed in the open press system (as shown in Fig. 1a).The specimens were stored in a chamber at $20{ }^{\circ} \mathrm{C}$ and $65 \%$ relative humidity $(\mathrm{RH})$ until their equilibrium moisture content was reached.

Table 1. Groups of Specimens According to Treatment

\begin{tabular}{|c|c|c|c|c|}
\hline \multicolumn{2}{|c|}{ Sample Groups } & $\begin{array}{c}\text { Compression } \\
\text { Ratios } \\
(\%)\end{array}$ & $\begin{array}{c}\text { Thermal } \\
\text { Treatment } \\
\text { Temperature } \\
\left({ }^{\circ} \mathrm{C}\right)\end{array}$ & $\begin{array}{c}\text { Thermal } \\
\text { Treatment } \\
\text { Duration }(\mathrm{h})\end{array}$ \\
\hline NW & Natural Wood & - & - & - \\
\hline $\begin{array}{c}\text { Densifi } \\
\text { cation }\end{array}$ & Densification-30\% & 30 & - & - \\
\cline { 2 - 5 } $\begin{array}{c}\text { THM- } \\
\text { CR }\end{array}$ & Densification-50\% & 50 & - & - \\
\cline { 2 - 5 } & $\mathrm{THM}-0 \%$ & 0 & 180 & 3 \\
\hline \multirow{3}{*}{ THM-T } & $\mathrm{THM}-30 \%$ & 30 & 180 & 3 \\
\cline { 2 - 5 } & $\mathrm{THM}-50 \%$ & 50 & 180 & 3 \\
\cline { 2 - 5 } & $\mathrm{THM}-180^{\circ} \mathrm{C}$ & 30 & 180 & 3 \\
\hline \multirow{3}{*}{ THM-D } & $\mathrm{THM}-200^{\circ} \mathrm{C}$ & 30 & 200 & 3 \\
\cline { 2 - 5 } & $\mathrm{THM}-20^{\circ} \mathrm{C}$ & 30 & 220 & 3 \\
\cline { 2 - 5 } & $\mathrm{THM}-3 \mathrm{~h}$ & 30 & 200 & 4 \\
\hline
\end{tabular}

\section{Methods}

Density and testing the density profile

The densities of the wood samples were measured with a standard procedure described in the GB/T 1933 (2009). The samples were kept in the oven chamber at a temperature of $103{ }^{\circ} \mathrm{C}$, until a constant weight was reached. The mass and dimensions (longitudinal, tangential, and radial) of each sample were measured with an analytical balance $( \pm 0.001 \mathrm{~g})$ and a vernier caliper $( \pm 0.001 \mathrm{~mm})$, which were used to determine the weight $\left(m_{0}\right)$ and volumes $\left(V_{0}\right)$, respectively. The oven-dried density $\left(\rho_{0}\right)\left(\mathrm{g} / \mathrm{cm}^{3}\right)$ was calculated using Eq. 1:

$$
\rho_{0}=\frac{m_{0}}{V_{0}}
$$

Determining the density profile of the wood samples was performed with a GreCon DAX 5000 tester. Specimens with dimensions of $50 \mathrm{~mm}$ (longitudinal) x $50 \mathrm{~mm}$ (tangential) $\mathrm{x}$ compressed size (radial) were prepared from the oven-dried compressed specimens, and were used to measure the density profile via a combination of X-ray sensors (where measurements can be made up to $1 \mathrm{~mm}$ per second). In this experiment, the narrow $\mathrm{X}$-ray beam was projected to the specimens tangentially and then scanned in the thickness direction to generate a density profile. 
Testing the modulus of elasticity (MOE) and modulus of rupture (MOR)

The bending deformation was measured using a Tinius Olsen H5KT tester with a standard procedure described in the GB/T 1963.1-2009 and GB/T 1963.2-2009. The sample dimensions were approximately $300 \mathrm{~mm}$ (longitudinal) by $20 \mathrm{~mm}$ (tangential) by the compressed size (radial). Three-point bending tests were conducted on each sample, with the span between the two bottom rollers equaling $240 \mathrm{~mm}$ and the top roller pressing down at the centre at a speed of $2 \mathrm{~mm} \mathrm{~min}^{-1}$.

\section{Testing the radial hardness}

The radial hardness of the wood samples was determined with a Tinius Olsen H5KT tester with a standard procedure described in the GB/T 1941-2009. The dimensions for hardness samples were approximately $50 \mathrm{~mm}$ (longitudinal) x $50 \mathrm{~mm}$ (tangential) x compressed size (radial). The pressing ball had a diameter $5.64 \mathrm{~mm}$ with a penetration depth of $5.64 \mathrm{~mm}$. The test was performed with a rate of penetration of $3 \mathrm{~mm} \mathrm{~min}^{-1}$. The static radial hardness was calculated as $K \times P$, where $K$ is the coefficient of the penetration depth (5.64) and $P$ is the applied maximum force.

\section{Testing the thickness swelling}

Determination of thickness swelling of the wood samples was based on the standard procedure described in GB/T 1934.2-2009. Treated specimens were oven-dried for more than $12 \mathrm{~h}$ to determine their dry dimensions and masses. After that, all specimens with dimensions of approximately $20 \mathrm{~mm}$ (longitudinal) x $20 \mathrm{~mm}$ (tangential) x compressed size (radial) were placed in a chamber under conditions of $25^{\circ} \mathrm{C}$ and $60 \% \mathrm{RH}$ for 1 week to determine their stable dimensions and masses. Next, all specimens were soaked in water at $25{ }^{\circ} \mathrm{C}$, and the dimensions and masses after soaking in water were recorded. The thickness swelling was calculated using Eq. 2,

$$
\mathrm{R}_{\max }=\frac{L_{\max }-L_{0}}{L_{0}} \times 100
$$

where $R_{\max }(\mathrm{mm})$ is the compression set recovery along the thickness direction after swelling, $L_{0}(\mathrm{~mm})$ is the oven-dried thickness before setting recovery occurred, and $L_{\max }$ $(\mathrm{mm})$ is the thickness of the wood sample after swelling.

\section{RESULTS AND DISCUSSION}

\section{Density Profile Analysis}

The density profile is the density distribution along the thickness that affects the mechanical and physical properties of wood (Rautkari et al. 2013). The density profiles of the untreated and treated wood samples (CR 30\% and CR 50\%) were presented in Fig. 2a and $2 \mathrm{~b}$, respectively. Because densification occurs in two surface layers, due to softening under the high temperature of the press plate, a symmetrical density profile was expected. The surface layers have higher densities than the core area; however, the density at the core layer was still greater than the density of untreated wood. An increase in the exerted pressure can increase the maximum density as well as the minimum density. For the samples with a CR of 50\% the maximum and minimum densities were 941.8 and 634.8 $\mathrm{kg} / \mathrm{m}^{3}$, respectively, for samples with a CR of $30 \%$ the maximum and minimum densities were 759.5 and $406.9 \mathrm{~kg} / \mathrm{m}^{3}$, respectively, while for samples with a CR of $0 \%$ the 
maximum and minimum densities were 479.7 and $376.1 \mathrm{~kg} / \mathrm{m}^{3}$, respectively. The maximum and minimum densities of the untreated wood samples were 473.3 and 388.5 $\mathrm{kg} / \mathrm{m}^{3}$, respectively, which corresponded to the densities of latewood and earlywood. Different studies have shown that density increases as the compression ratio increases (Blomberg et al. 2005; Arruda and Menezzi 2013).
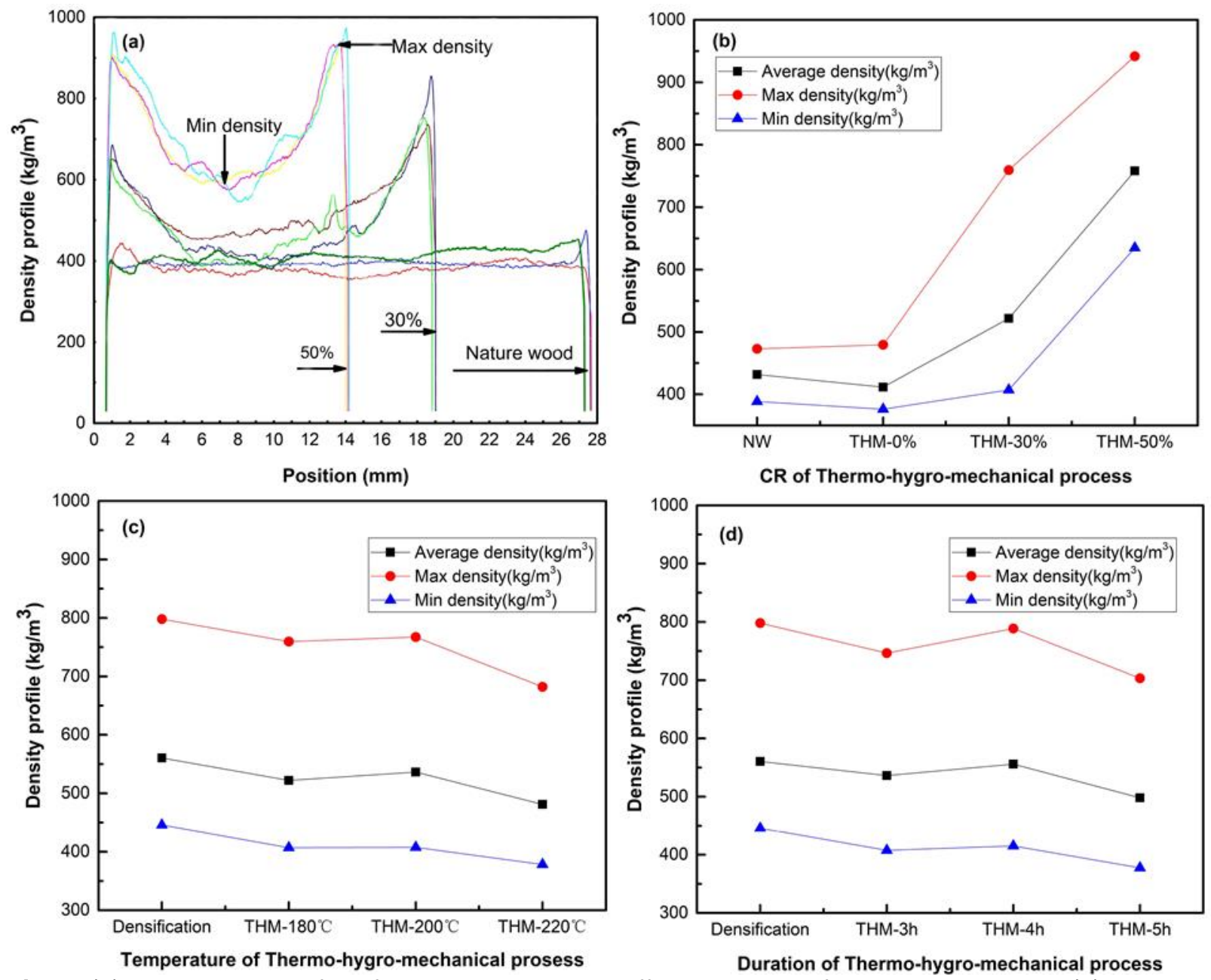

Fig. 2. (a): The density profile of the specimens with different degree of compression ratios; (b): Influence of the compression ratio of the thermo-hydro-mechanical process on the average $(n=$ 18) density profile of poplar (Populus) wood; (c): Influence of the thermal treatment temperatures of the thermo-hydro-mechanical process on the average $(n=18)$ density profile of poplar (Populus) wood; and (d): Influence of the thermal treatment duration of the thermo-hydromechanical process on the average $(n=18)$ density profile of poplar (Populus) wood

Densification is an effective way to convert low-density wood into a denser, harder material (Dwianto et al. 1998; Kariz et al. 2017; Kúdela et al. 2018). Thermal modification is the simplest and probably the most cost-efficient method of doing so (Wehsener et al. 2018; Tomislav et al. 2019). It was found that thermal modification at temperatures greater than $160 \quad{ }^{\circ} \mathrm{C}$, in an oxygen free environment, causes permanent changes to the mass, density, and mechanical properties of wood ( $\mathrm{Li}$ et al. 2017, 2018). This study also examined the effects of the temperature and duration on the density profile of densified wood (Fig. 2c and $2 \mathrm{~d}$ ). The density profile of the densified samples that underwent thermal posting 
treatment did not differ drastically from the density profile of densified wood that did not undergo thermal posting treatment. However, in samples with thermal modification temperatures of $180^{\circ} \mathrm{C}$ and $200{ }^{\circ} \mathrm{C}$, a decrease in density was observed, while the samples with thermal modification temperature of $220{ }^{\circ} \mathrm{C}$ differed from the densification-30\% samples (Fig. 2c). The effects of the thermal modification duration on the density profile of the sample led to a similar conclusion, in which the samples with thermal modification duration of $5 \mathrm{~h}$ differed from the densification-30\% samples (Fig. 2d). During treatment, the loss of wood mass and the decrease in equilibrium moisture content lead to a decrease in total wood density (Pelit et al. 2018). Thermal treatment causes wood degradation, especially from the decomposition of hemicelluloses. Hemicelluloses generate acetic acid during heat treatment, which further catalyzes carbohydrate cleavage, resulting in a decrease of the degree of carbohydrate polymerization (Popescu et al. 2011). Thermal modification causes mass loss, and mass loss directly affects the density profile of wood (Esteves et al. 2008; Rautkari et al. 2013; Pelit et al. 2019).

\section{MOE and MOR Analysis}

The mechanical properties of the densification samples were drastically higher than untreated wood. The MOE and MOR of the treated samples, under different THM treatment conditions, are presented in Fig. $3 \mathrm{a}$ and $3 \mathrm{~b}$. These results showed a major increase in the MOE and MOR due to the increase in the density resulting from the increase in the compression ratio (ranging from $0 \%$ to $50 \%$ ). The densified wood with a compression rate of 50\% demonstrated the greatest MOE and MOR values (13,900 MPa and $131 \mathrm{MPa}$, respectively), which were 3.84 and 2.61 times greater than natural wood.

The thermal modification temperature and duration affects the mechanical strength of densified wood. To characterize mechanical strength changes due to variation in the temperature and duration and the effect of thermal modification on the MOE and MOR, the treated samples at various temperatures $\left(180^{\circ} \mathrm{C}, 200^{\circ} \mathrm{C}\right.$, and $\left.220{ }^{\circ} \mathrm{C}\right)$ and durations $(3$ $\mathrm{h}, 4 \mathrm{~h}$, and $5 \mathrm{~h}$ ) were measured. The MOE value of compressed wood with a CR of $30 \%$ was $11,800 \mathrm{MPa}$ under thermal modification conditions of $3 \mathrm{~h}$ at $200{ }^{\circ} \mathrm{C}$, which was noticeable higher than the MOE values at thermal modification temperatures of $180^{\circ} \mathrm{C}$ and $220^{\circ} \mathrm{C}$ (Fig. 3a). However, thermal modification did noticeably influence the MOR values. Thermal modification temperatures of $180{ }^{\circ} \mathrm{C}$ and $200{ }^{\circ} \mathrm{C}$ reduced the MOR value to 84.3 $\mathrm{MPa}$ and $87.6 \mathrm{MPa}$, respectively (Fig. 3b). When the thermal modification temperature reached $220^{\circ} \mathrm{C}$, the MOR value sharply dropped. The MOE and MOR were also measured for samples with different treatment durations. A longer duration did not affect MOE values. A thermal modification duration of $4 \mathrm{~h}$ and $5 \mathrm{~h}$ reduced the MOE to $69.7 \mathrm{MPa}$ and 67.2 MPa. The MOR values were reduced after wood samples were subjected to higher treatment temperatures $\left(220^{\circ} \mathrm{C}\right)$ and longer treatment times $(5 \mathrm{~h})$.

The mechanical properties noticeably increased due to densification, as well as increasing with an increase in compression ratios (Zhan and Avramidis 2017). In terms of natural wood samples, the highest air-dried density was found in densification samples with a CR of $50 \%$, and the value increased by approximately $84.2 \%$. The mechanical strengths (MOE and MOR) and density exhibited a positive linear correlation with the correlation coefficients, which were 0.86 and 0.8206 , respectively (Fig. $3 \mathrm{c}$ and $3 \mathrm{~d}$ ). 

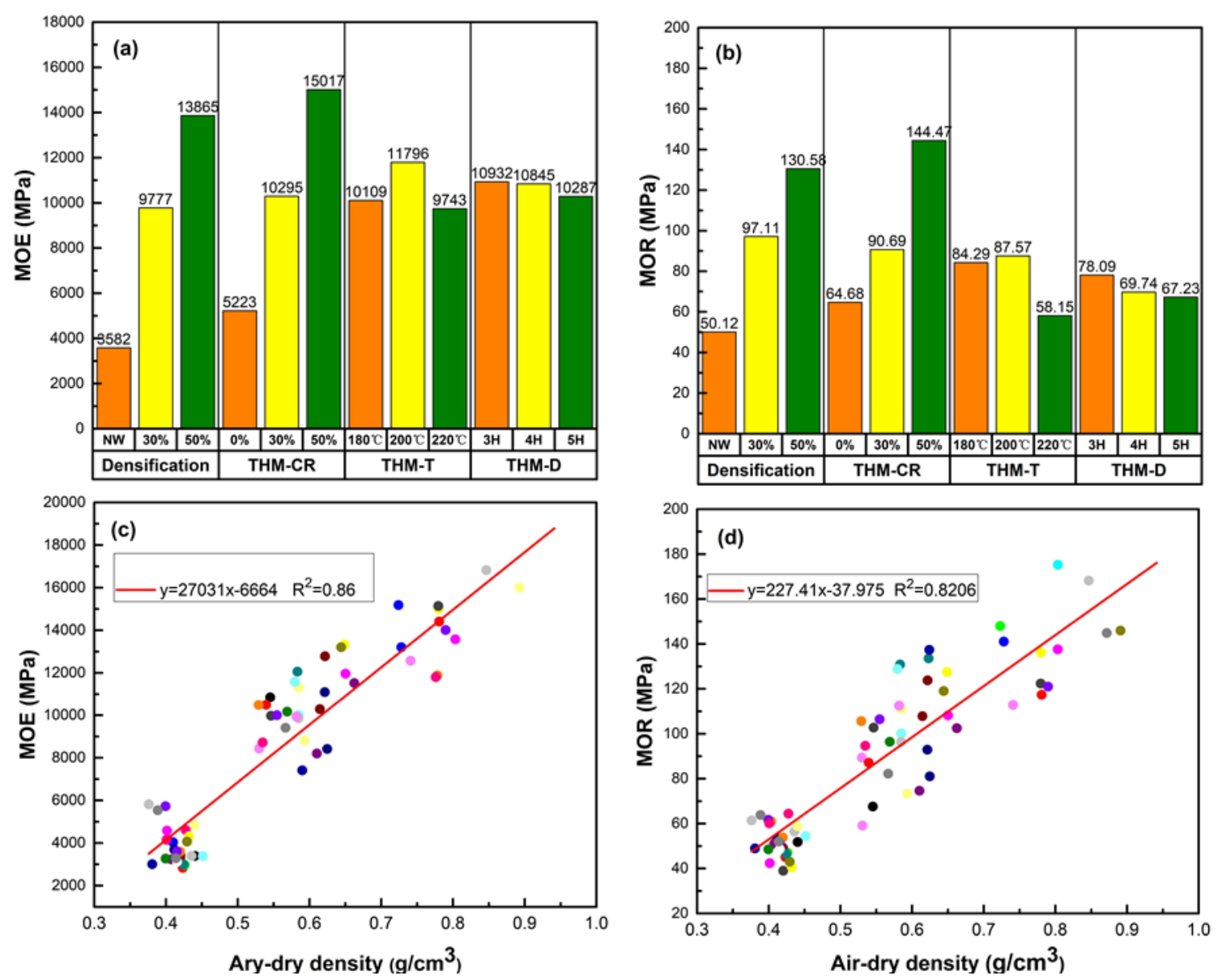

Fig. 3. (a): Influence of the different parameters of the thermo-hydro-mechanical process on the average $(n=10)$ MOE values of poplar (Populus) wood; $(b)$ : Influence of the different parameters of the thermo-hydro-mechanical process on the average $(n=10)$ MOR values of poplar (Populus) wood; (c): Correlation between Air-dry density and MOE of nature wood and thermo-hydromechanical modified poplar (Populus) wood; and (d): Correlation between Air-dry density and MOR of nature wood and thermo-hydro-mechanical modified poplar (Populus) wood

In general, deformation had a greater change of occurrence in the earlywood, which has thinner and weaker cell walls in comparison to latewood. However, a higher heat treatment temperature and longer heat treatment duration will thermally decompose chemical components, which results in quality loss, and a reduction of the mechanical properties of the treated sample (Esteves and Pereira 2009).

\section{Radial Hardness Analysis}

In this study, the radial hardness of the treated samples and natural wood control were measured. The radial hardness values when the compression ratio, heat treatment temperature, and duration were altered, as presented in Fig. 4. The radial hardness increased with an increase in the compression ratio. According to results shown in Fig. 4a, the highest radial hardness $(3.09 \mathrm{KN})$ was found in the samples with a compression ratio of $50 \%$, whereas the lowest hardness value $(1.47 \mathrm{KN})$ was found in the undensified samples. The mean difference in the hardness values was approximately $110 \%$, while the density values were higher in samples with a compression ratio of $50 \%\left(768 \mathrm{~kg} / \mathrm{m}^{3}\right)$ than in the undensified samples $\left(395 \mathrm{~kg} / \mathrm{m}^{3}\right)$. In other studies, it has been reported that the 
hardness of woody materials is closely related to the compression ratio, and that the hardness values increase as the compression ratio is increased (Ünsal et al. 2011; Gašparík et al. 2016). The correlation between the radial hardness and the air-dried density of the samples that underwent thermal treatment and the control are shown in Fig. 4d. The changes in the density of the wood sample affected the radial hardness of the samples that underwent thermal treatment, relative to the control.
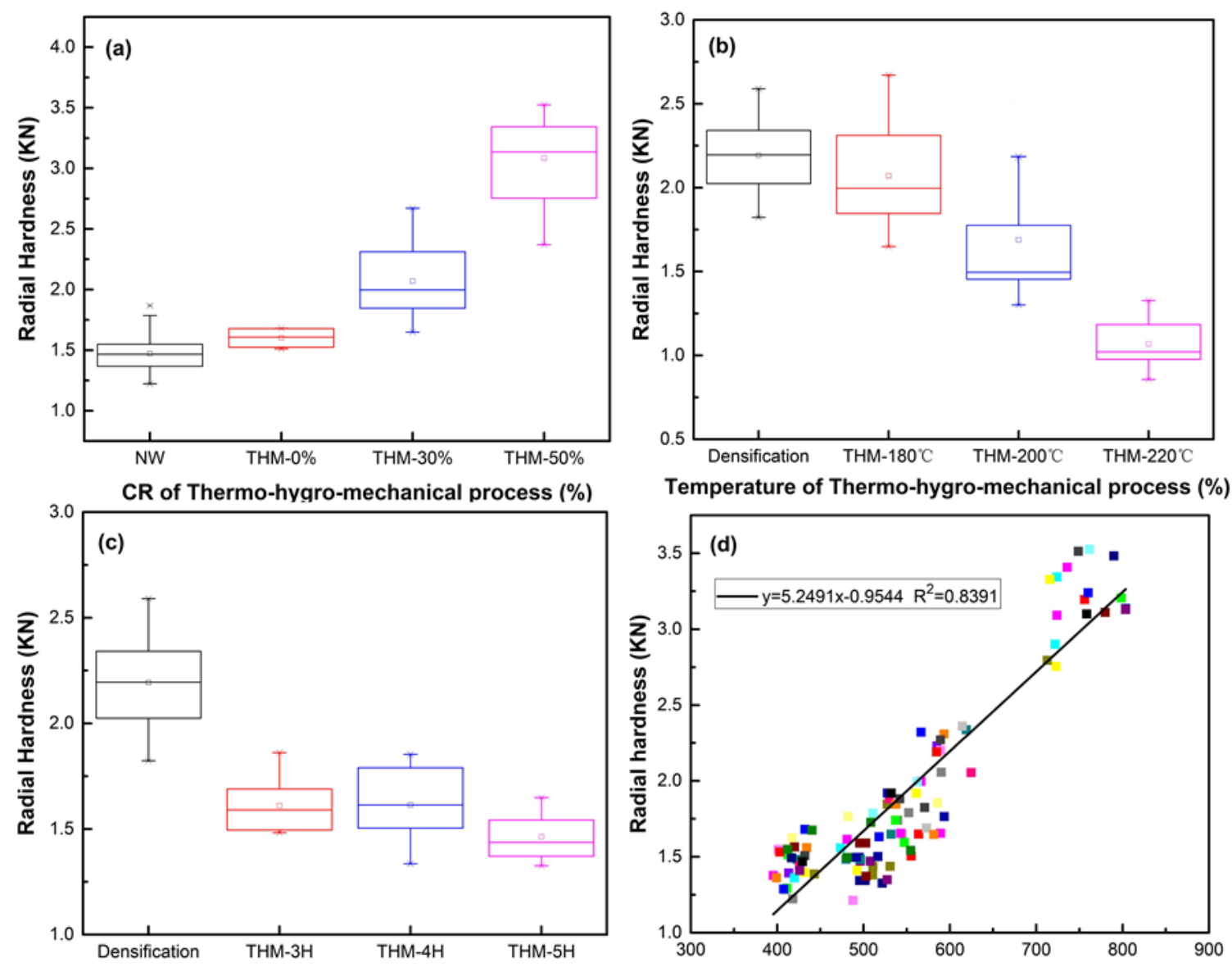

Duration of Thermo-hygro-mechanical process (\%)

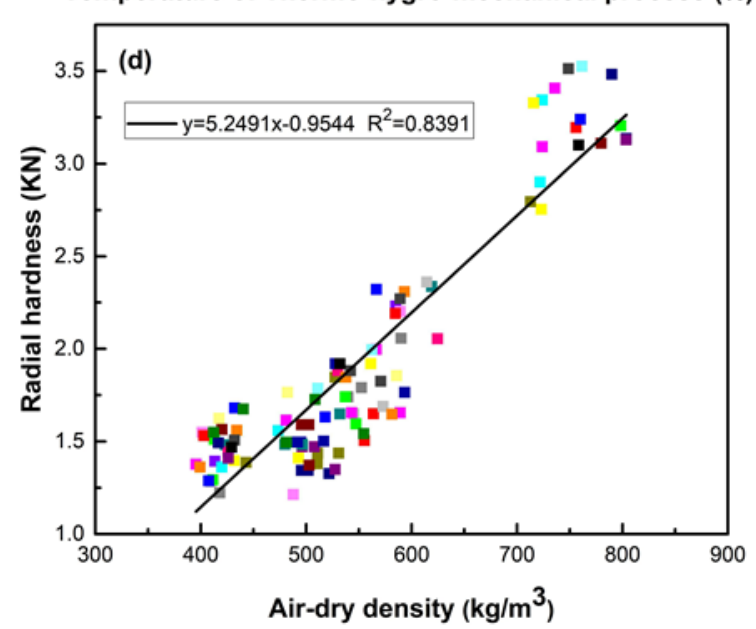

Fig. 4. (a): Influence of the CR of the thermo-hydro-mechanical process on the average $(n=15)$ radial hardness of poplar (Populus) wood; (b): Influence of the temperature of the thermo-hydromechanical process on the average $(n=15)$ radial hardness of poplar (Populus) wood; (c): Influence of the duration of the thermo-hydro-mechanical process on the average $(n=15)$ radial hardness of poplar (Populus) wood; (d): Correlation between the air-dried density and radial hardness of natural wood and thermo-hydro-mechanical modified poplar (Populus) wood samples

The radial hardness decreased as the treatment temperature and duration increased (Figs. 4b and 4c). The densified wood subjected to a treatment temperature of $180{ }^{\circ} \mathrm{C}$ had a lower radial hardness $(6.4 \%)$ and densified wood subjected to a treatment temperature of $200{ }^{\circ} \mathrm{C}$ and $220{ }^{\circ} \mathrm{C}$ had a decrease in radial hardness of $22.8 \%$ and $51.6 \%$, respectively. When a thermal treatment duration of $3 \mathrm{~h}, 4 \mathrm{~h}$, or $5 \mathrm{~h}$ was applied with a treatment temperature of $200{ }^{\circ} \mathrm{C}$, the mean radial hardness was reduced to $1.69 \mathrm{KN}, 1.61 \mathrm{KN}$, and $1.46 \mathrm{KN}$, respectively. The radial hardness values gradually decreased as the thermal treatment duration increased. However, the hardness value gradually decreased as the thermal treatment temperature and duration increased (Perçin 2012; Fang et al. 2012b; 
Agnieszka 2017). The temperature and duration of the thermal treatment accounted for $30 \%$ of the wood hardness variability, whereas the interaction between temperature and duration accounted for $23 \%$ of the wood hardness variability (Agnieszka 2017).

The decrease in hardness can be attributed to the degradation of polysaccharides and the loss of mass (Pelit et al. 2017). The total cellulose and hemicellulose content decreased with an increase in temperature and duration of treatment. The change in hemicellulose content was dependent on the temperature. Most of the hemicelluloses were degraded when the sample was exposed to thermal treatment temperatures and durations of $220^{\circ} \mathrm{C}$ for $3 \mathrm{~h}$ or $200^{\circ} \mathrm{C}$ for $5 \mathrm{~h}$ (Li et al. 2016).

\section{Thickness Swelling Analysis}

The results of analyzing the water-soaked thickness swelling values of the treated samples are illustrated in Fig. 5. Before the thermal treatments, when compared to the nondensified samples, the thickness swelling values were $29.7 \%$ and $41.6 \%$ at compression ratios of $30 \%$ and $50 \%$, respectively. Compared to the untreated samples, the thickness swelling values were less in the treated samples. Wood has a shape memory effect, i.e., when densified wood is soaked in water or exposed to a high relative humidity, it will bound back (Ugolev 2014). The internal stress generated by the compression is relieved, and the cell wall absorbs water and expands, returning to its original shape (Pelit et al. 2016).

The thickness swelling values decreased with an increase in the temperature and duration of treatment (Fig. 5).

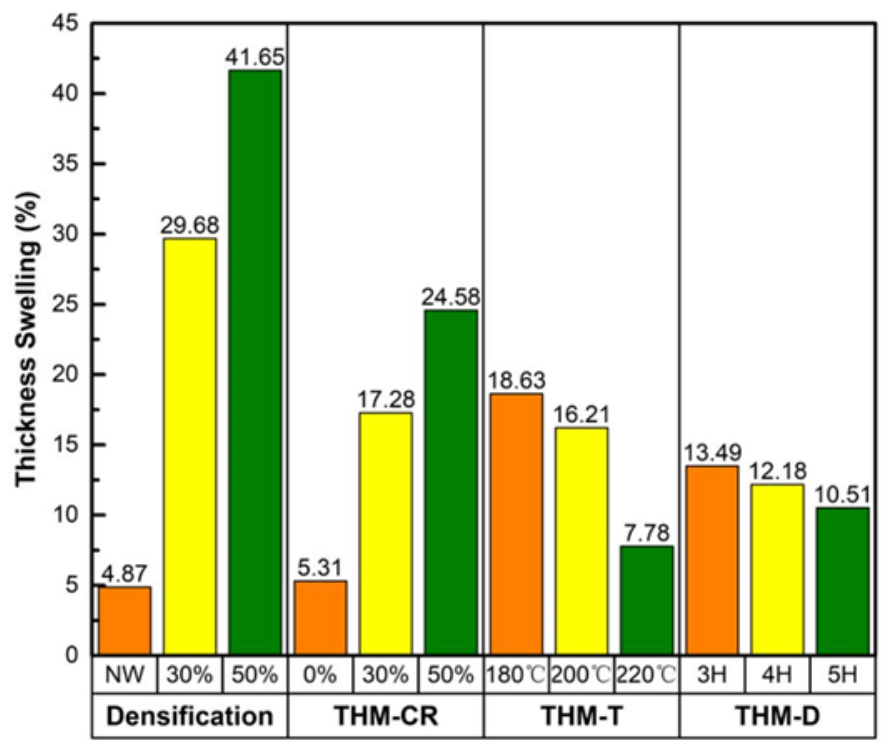

Fig. 5. Influence of different parameters of the thermo-hydro-mechanical process on the average $(n=20)$ thickness swelling of poplar (Populus) wood

The maximum thickness swelling was reduced by $74 \%$ (from $29.7 \%$ to $7.8 \%$ ) in samples that underwent thermal treatment conditions of $220{ }^{\circ} \mathrm{C}$ for $3 \mathrm{~h}$. The thermal temperature had more influence on the thickness swelling values of densified wood than the thermal treatment duration. The dimensional stability was greatly improved with thermal treatment temperatures greater than $180{ }^{\circ} \mathrm{C}$ (Fukuta et al. 2008; Fang et al. 2012a). Several factors contributed to the increase in the dimensional stability of the thermal treated 
wood: less hygroscopic hemicelluloses, the bridging of cellulose chains, and the crosslinking of the aromatic rings found in the lignins (Kocaefe et al. 2015).

\section{CONCLUSIONS}

1. After densification due to heat treatment and compression, an increase in density was observed in poplar samples, in proportion to the compression ratio (CR). Thermal treatment causes wood degradation, especially from the decomposition of hemicelluloses. Thermal modification causes mass loss, and mass loss directly affects the density of wood. The density decreased $4.6 \%$ in samples with thermal treatment conditions of $200{ }^{\circ} \mathrm{C}$ for $5 \mathrm{~h}$.

2. The modulus of elasticity (MOE) and modulus of rupture (MOR) values of the treated poplar samples increased as the compression ratio increased. The mechanical strengths and density have a positive linear correlation with the correlation coefficients. However, a higher heat treatment temperature and longer heat treatment duration will thermally decompose chemical components, which results in quality loss, and a reduction of the mechanical properties of the treated sample.

3. The hardness of poplar is closely related to the compression ratio, and the hardness value increases with the increase of compression ratio. At a compression ratio of $50 \%$, the hardness increased from 1.47 to $3.09 \mathrm{KN}$. The radial hardness gradually decreased as the treatment temperature and duration increased. The decrease in hardness can be attributed to the degradation of polysaccharides and the loss of mass.

4. The dimensional stability was improved by the thermal treatment. Compared to the densified sample, the maximum thickness swelling value was reduced by $74 \%$ (from $29.7 \%$ to $7.8 \%$ ) through thermal treatment conditions of $220^{\circ} \mathrm{C}$ for $3 \mathrm{~h}$ duration. The reduction of hygroscopic hemicellulose, the bridging of cellulose chains, and the crosslinking of aromatic rings in lignin are the reasons for the increase of dimensional stability of the thermal treated wood.

\section{ACKNOWLEDGMENTS}

The authors gratefully acknowledge the financial support from the Science and Technology Projects of the Inner Mongolia Autonomous Region (201802031) and the National Natural Science Foundation of the Inner Mongolia Autonomous Region (2019MS03059).

\section{REFERENCES CITED}

Agnieszka, L. (2017). "The influence of process parameters on the density profile and hardness of surface-densified birch wood (Betula pendula Roth)," BioResources 12(3), 6011-6023. DOI: 10.15376/biores.12.3.6011-6023

Arruda, L. M., and Menezzi, C. H. S. (2013). "Effect of thermomechanical treatment on physical properties of wood veneers," International Wood Products Journal 4(4), 
217-224. DOI: $10.1179 / 2042645312 y .0000000022$

Belt, T., Rautkari, L., Laine, K. and Hill, C. A. S. (2013). "Cupping behaviour of surface densified Scots pine wood: The effect of process parameters and correlation with density profile characteristics," Journal of Materials Science 48(18), 6426-6430. DOI: $10.1007 / \mathrm{s} 10853-013-7443-1$

Blomberg, J., Persson, B., and Blomberg, A. (2005). "Effects of semi-isostatic densification of wood on the variation in strength properties with density," Wood Science and Technology 39, 339-350. DOI: 10.1007/s00226-005-0290-8

Boonstra, M. J., and Tjeerdsma, B. (2006). "Chemical analysis of heat treated softwoods," European Journal of Wood and Wood Products 64(3), 204-211. DOI: 10.1007/s00107005-0078-4

Drafz, M. H. H., Franz, A., Namyslo, J. C., and Kaufmann, D. E. (2015). "Chemistry and spectroscopy of renewable materials, Part 1: Imaging the penetration depth of covalent wood modification," ACS Sustainable Chemistry \& Engineering 3(4), 566568. DOI: $10.1021 / \mathrm{sc} 5008048$

Dwianto, W., Norimoto, M., Morooka. T., Tanaka, F., Inoue, M., and Liu, Y. (1998). "Radial compression of sugi wood (Cryptomeria japonica D. Don)," European Journal of Wood and Wood Products 56(6), 403-41. DOI: 10.1007/s001070050342

Dwianto, T., Morooka, T., and Norimoto, M. (2000). "Compressive creep of wood under high temperature steam," Holzforschung 54(1), 104-108. DOI: 10.1515/hf.2000.017

Esteves, B. M., Domingos, I. J., and Pereira, H. M. (2008). "Pine wood modification by heat treatment in air," BioResources 3(1), 142-154. DOI: 10.15376/biores.3.1.142154

Esteves, B., and Pereira, H. (2009). "Wood modification by heat treatment: A review," BioResources 4(1), 370-404. DOI: 10.15376/biores.4.1.136-146

Fang, C.-H., Cloutier, A., Blanchet, P., and Koubaa, A. (2012b). "Densification of wood veneers combined with oil-heat treatment. Part II: Hygroscopicity and mechanical properties," BioResources 7(1), 925-935. DOI: 10.15376/biores.7.1.925-935

Fang, C.-H., Mariotti, N., Cloutier, A., Koubaa, A., and Blanchet, P. (2012a). "Densification of wood veneers by compression combined with heat and steam," European Journal of Wood and Wood Products 70(1-3), 155-163. DOI: 10.1007/s00107-011-0524-4

Fukuta, S., Asada, F., and Sasaki, Y. (2008). "The simultaneous treatment of compression drying and deformation fixation in the compression processing of wood," Forest Products Journal 58(7), 82-88.

Gao, Z., Huang, R., Lu, J., Chen, Z., Guo, F., and Zhan, T. (2016). "Sandwich compression of wood: Control of creating density gradient on lumber thickness and properties of compressed wood," Wood Science and Technology 50(4), 833-844. DOI:10.1007/s00226-016-0824-2

Gašparík, M., Gaff, M., Šafaříková, L., Vallejo, C. R., and Svoboda, T. (2016). "Impact bending strength and Brinell hardness of densified hardwoods," BioResources 11(4), 8638-8652. DOI: $10.15376 /$ biores.11.4.8638-8652

GB/T 1933 (2009). "Method for determination of the density of wood," Standardization Administration of China, Beijing, China.

GB/T 1934.2 (2009). "Method for determination of the swelling of wood," Standardization Administration of China, Beijing, China.

GB/T 1936.1 (2009). "Method of testing in bending strength of wood," Standardization Administration of China, Beijing, China. 
GB/T 1936.2 (2009). "Method for determination of the modulus of elasticity in static bending of Wood," Standardization Administration of China, Beijing, China.

GB/T 1941 (2009). "Method of testing in hardness of wood," Standardization Administration of China, Beijing, China.

Gong, M., Lamason, C., and Li, L. (2010). "Interactive effect of surface densification and post-heat-treatment on aspen wood," Journal of Materials Processing Technology 210(2), 293-296. DOI: 10.1016/j.jmatprotec.2009.09.013

Inoue, M., Norimoto, M., Tanahashi, M., and Rowell, R. M. (1993). "Steam or heat fixation of compressed wood," Wood and Fiber Science 25(3), 224-235.

Kariz, M., Kuzman, M. K., Sernek, M., Hughes, M., Rautkari, L., Kamke, F. A., and Kutnar, A. (2017). "Influence of temperature of thermal treatment on surface densification of spruce," European Journal of Wood and Wood Products 75(1), 113123. DOI: $10.1007 / \mathrm{s} 00107-016-1052-\mathrm{z}$

Kocaefe, D., Huang, X., and Kocaefe, Y. (2015). "Dimensional stabilization of wood," Current Forestry Reports 1(3), 151-161. DOI: 10.1007/s40725-015-0017-5

Kollmann, F. F. P., Kuenzi, E. W., and Stamm, A. J. (1975). Principles of Wood Science and Technology. Vol. II: Wood Based Materials, Springer-Verlag, New York, NY.

Kúdela, J., Rousek, R., Rademacher, P., Rešetka, M., and Dejmal, A. (2018). "Influence of pressing parameters on dimensional stability and density of compressed beech wood," European Journal of Wood and Wood Products 76(1), 1241-1252. DOI: 10.1007/s00107-018-1298-8

Kutnar, A., and Šernek, M. (2007). "Densification of wood," Zbornik Gozdarstva in Lesarstva (82), 53-62.

Kutnar, A., Kamke, F. A., and Sernek, M. (2008). "The mechanical properties of densified VTC wood relevant for structural composites," European Journal of Wood and Wood Products 66(6), 439-446. DOI: 10.1007/s00107-008-0259-z

Kutnar, A., Kamke, F. A., and Sernek, M. (2009). "Density profile and morphology of viscoelastic thermal compressed wood," Wood Science and Technology 43(1-2), 5768. DOI: $10.1007 / \mathrm{s} 00226-008-0198-1$

Kutnar, A., and Kamke, F. A. (2012). "Influence of temperature and steam environment on set recovery of compressive deformation of wood," Wood Science and Technology 46, 953-964. DOI: 10.1007/s00226-011-0456-5

Kutnar, A., Sandberg, D., and Haller, P. (2015). "Compressed and moulded wood from processing to products," Holzforschung 69(7), 885-897. DOI: 10.1515/hf-2014-0187

Laine, K., Segerholm, K., Wålinder, M., Rautkari, L., and Hughes, M. (2016). "Wood densification and thermal modification: Hardness, set-recovery and micromorphology," Wood Science and Technology 50, 883-894. DOI: $10.1007 / \mathrm{s} 00226-016-0835-\mathrm{z}$

Li, H., Jiang, X., Ramaswamy, H. S., Zhu, S., and Yu, Y. (2018). "High-pressure treatment effects on density profile, surface roughness, hardness, and abrasion resistance of Paulownia wood boards," Transactions of the ASABE 61(3), 1181-1188. DOI: $10.13031 /$ trans.12718.

Li, L., Wang, X., and Wu, F. (2016). "Chemical analysis of densification, drying, and heat treatment of Scots pine (Pinus sylvestris L.) through a hot-pressing process," BioResources 11(2), 3856-3874. DOI: 10.15376/biores.11.2.3856-3874

Li, T., Cai, J.-B., Avramidis, S., Cheng, D.-L., Wålinder, M. E. P., and Zhou, D.G. (2017). "Effect of condition history on the characterization of hardness of thermomechanical densified and heat treated poplar wood," Holzforschung 71(6), 515- 
520. DOI: $10.1515 / \mathrm{hf}-2016-0178$

Navi, P., and Heger, F. (2004). "Combined densification and thermo-hydro-mechanical processing of wood," MRS Bulletin 29(5), 332-336. DOI: 10.1557/mrs2004.100

Pelit, H., Sönmez, A., and Budakçı, M. (2015). "Effects of thermomechanical densification and heat treatment on density and Brinell hardness of Scots pine (Pinus sylvestris L.) and eastern beech (Fagus orientalis L.)," BioResources 10(2), 30973111. DOI: 10.15376/biores.10.2.3097-3111

Pelit, H., Budakçı, M., and Sönmez, A. (2016). "Effects of heat post-treatment on dimensional stability and water absorption behaviours of mechanically densified Uludağ fir and black poplar woods," BioResources 11(2), 3215-3229. DOI: 10.15376/biores.11.2.3215-3229

Pelit, H., and Yalçın, M. (2017). "Resistance of mechanically densified and thermally post-treated pine sapwood to wood decay fungi," Journal of Wood Science 63(5), 514-522. DOI: 10.1007/s10086-017-1641-4

Pelit, H., Budakçı, M., and Sönmez, A. (2018). "Density and some mechanical properties of densified and heat post-treated Uludağ fir, linden and black poplar woods," European Journal of Wood and Wood Products 76(1), 79-87. DOI: 10.1007/s00107017-1182-y

Pelit, H., and Yorulmaz, R. (2019). "Influence of densification on mechanical properties of thermally pretreated spruce and poplar wood," BioResources 14(4), 9739-9754. DOI: 10.15376/biores.114.4.9739-9754

Perçin, O. (2012). Investigation of Some Technological Properties of The Laminated Wood Material Applied Heat Treatment, Ph.D. Dissertation, Gazi University, Ankara, Turkey.

Popescu, C.-M., Popescu, M.-C., and Vasile, C. (2011). "Structural analysis of photodegraded lime wood by means of FT-IR and 2D IR correlation spectroscopy," International Journal of Biological Macromolecules 48(4), 667-675. DOI: 10.1016/j.ijbiomac.2011.02.009

Popescu, M.-C., Lisa, G., Froidevaux, J., Navi, P., and Popescu, C.-M. (2014). "Evaluation of the thermal stability and set recovery of thermo-hydro-mechanically treated lime (Tilia cordata) wood," Wood Science and Technology 48, 85-97. DOI: 10.1007/s00226-013-0588-x

Rautkari, L., Laine, K., Kutnar, A., Medved, S., and Hughes, M. (2013). "Hardness and density profile of surface densified and thermally modified Scots pine in relation to degree of densification," Journal of Materials Science 48(6), 2370-2375. DOI: 10.1007/s10853-0127019-5

Sandberg, D., Haller, P., and Navi, P. (2013). "Thermo-hydro and thermo-hydromechanical wood processing: An opportunity for future environmentally friendly wood products," Wood Materials Science \& Engineering 8(1), 64-88. DOI: 10.1080/17480272.2012.751935

Song, J., Chen, C., Zhu, S., Zhu, M., Dai, J., Ray, U., Li, Y., Kuang, Y., Li, Y., and Quispe, N. et al. (2018). "Processing bulk natural wood into a high-performance structural material," Nature 554, 224-228. DOI: 10.1038/nature25476

Sedlar, T., Sinković, T., Perić, I., Jarc, A., Stonjić, S., and Šefc, B. (2019). "Hardness of thermally modified beech wood and hornbeam wood," Šumarski List 143(9-10), 425433. DOI: $10.31298 / \mathrm{sl} .143 .9-10.4$

Tu, D., Su, X., Zhang, T., Fan, W., and Zhou, Q. (2014). "Thermo-mechanical densification of Populus tomentosa var. tomentosa with low moisture content," 
BioResources 9(3), 3846-3856. DOI: 10.15376/biores.9.3.3846-3856

Ugolev, B. N. (2014). "Wood as a natural smart material," Wood Science and Technology 48(3), 553-568. DOI: 10.1007/s00226-013-0611-2

Ünsal, Ö., Candan, Z., Büyüksarı, Ü., Korkut, S., Chang, Y.-S., and Yeo, H.-M. (2011). "Effect of thermal compression treatment on the surface hardness, vertical density propile and thickness swelling of eucalyptus wood boards by hot-pressing," Journal of the Korean Wood Science and Technology 39(2), 148-155. DOI: 10.5658/WOOD.2011.39.2.148

Wehsener, J., Brischke, C., Meyer-Veltrup, L., Hartig, J., and Haller, P. (2018). "Physical, mechanical and biological properties of thermo- mechanically densified and thermally modified timber using the vacu'-process," European Journal of Wood and Wood Products 76(3), 809-821. DOI: 10.1007/s00107-017-1278-4

Welzbacher, C. R., Wehsener, J., Rapp, A. O., and Haller, P. (2008). "Thermomechanical densification combined with thermal modification of Norway spruce (Picea abies Karst) in industrial scale - dimensional stability and durability aspects," European Journal of Wood and Wood Products 66(1), 39-49. DOI: 10.1007/s00107007-0198-0

Yin, J., Yuan, T., Lu, Y., Song, K., Li, H., Zhao, G., and Yin, Y. (2016). "Effect of compression combined with steam treatment on the porosity, chemical composition and cellulose crystalline structure of wood cell walls," Carbohydrate Polymers 155, 163-172. DOI: 10.1016/j.carbpol.2016.08.013

Zhan, J.-F., and Avramidis, S. (2017). "Transversal mechanical properties of surfacedensified and hydrothermally modified needle fir wood," Wood Science and Technology 51(4), 721-738. DOI: 10.1007/s00226-017-0909-6

Article submitted: July 7, 2020; Peer review completed: August 23, 2020; Revised version received and accepted: October 11, 2020; Published: October 29, 2020.

DOI: 10.15376/biores.15.4.9596-9610 